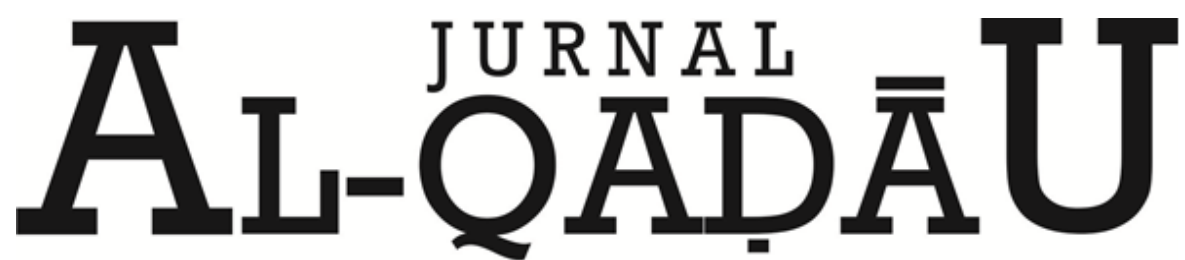 \\ PERADILAN dan HUKUM KELUARGA ISLAM
}

\section{Tantangan Undang-Undang Anti Monopoli dalam Pasar Bebas}

\section{Challenges Of Anti Monopoly Law on A Free Market}

Pratjaja Winrekso

Fakultas Hukum - Universitas Sawerigading Makassar

Email :winreksa@gmail.com

\begin{tabular}{|c|c|}
\hline $\begin{array}{c}\text { Info } \\
\text { Artikel }\end{array}$ & Abstract \\
\hline $\begin{array}{l}\text { Diterima } \\
09 \\
\text { Februari } \\
2017\end{array}$ & $\begin{array}{l}\text { Akibat globalisasi dan pasar bebas secara tidak langsung akan } \\
\text { mempegaruhi pasar di indonesia.. Pembentukan Komunitas Ekonomi } \\
\text { ASEAN merupakan salah satu contohnya. Oleh karena itu Undang- } \\
\text { Undang Ekonomi yang kuat maka persaingan tidak sehat dan praktek } \\
\text { monopoli dapat dihilangkan. Tantangan global undang-undang nomor } 5 \\
\text { tahun } 1999 \text { tentang larangan praktek monopoli dan persaingan tidak } \\
\text { sehat di pasar bebas sangat penting sebagai perlindungan hukum } \\
\text { terhadap produk dan industry dalam negeri dan memberikan kepastian } \\
\text { hukum juga poduk dari luar negeri. Produk dan industry dalam negeri } \\
\text { akan mendapatkan kepastian hukum baik dari segi masalah persaingan } \\
\text { tidak sehat maupun antisipasi pratek monopoli. } \\
\text { Kata kunci: UU Anti Monopoli, Pasar Bebas, Ekonomi Pasar }\end{array}$ \\
\hline $\begin{array}{l}\text { Disetujui } \\
22 \\
\text { Mei } \\
2017\end{array}$ & $\begin{array}{l}\text { As a result of globalization, indirectly, the free market culture (free trade } \\
\text { market) who brought the liberals will also affect the market in Indonesia. } \\
\text { The establishment of the ASEAN Economic Community is one example. } \\
\text { Therefore a strong Economic Law that did not happen and the market } \\
\text { monopoly unfair competition can be eliminated. Global challenges } \\
\text { Indonesian Act No. } 5 \text { of } 1999 \text { on Antitrust and Unfair Competition in the } \\
\text { free market more important is the legal protection of the products and the } \\
\text { domestic industry is the main and more legal certainty for products that } \\
\text { come from abroad. Products and the domestic industry also obtain legal } \\
\text { certainty both in terms of problems of unfair competition as well as } \\
\text { anticipation of monopoly. }\end{array}$ \\
\hline
\end{tabular}

Keywords: Anti Monopoly Law, Free Market, Market Economy 


\section{Pendahuluan}

Dunia usaha merupakan suatu dunia yang boleh dikatakan tidak dapat berdiri sendiri. Banyak aspek dari berbagai macam dunia lainnya turut terlibat langsung maupun tidak langsung dengan dunia usaha ini. Keterkaitan tersebut kadangkala tidak memberikan prioritas atas dunia usaha, yang pada akhirnya membuat dunia usaha harus tunduk dan mengikuti rambu-rambu yang ada dan seringkali bahkan mengutamakan dunia usaha sehingga mengabaikan aturan-aturan yang telah ada. ${ }^{1}$

Pesatnya perkembangan dunia usaha adakalanya tidak diimbangi dengan "penciptaan" rambu-rambu pengawas. Dunia usaha yang berkembang terlalu pesat sehingga meninggalkan rambu-rambu yang ada jelas tidak akan menguntungkan pada akhirnya. Apabila hukum tidak ingin dikatakan tertinggal dari perkembangan bisnis dan dunia usaha, maka hukum dituntut untuk merespon segala seluk beluk kehidupan dunia usaha yang melingkupinya sebagai suatu fenomena atau kenyataan sosial. Itu berarti, peran hukum menjadi semakin penting dalam menghadapi problema-problema dunia usaha yang timbul seperti Monopoli dan Persaingan Usaha Tidak Sehat.

Monopoli menggambarkan suatu keadaan dimana terdapat seseorang atau sekelompok orang yang menguasai suatu bidang tertentu secara mutlak, tanpa memberikan kesempatan kepada orang lain untuk ikut ambil bagian. Monopoli diartikan sebagai suatu hak istimewa (previlege), yang menghapuskan persaingan bebas, yang tentu pada akhirnya juga akan menciptakan penguasaan pasar. Pengertian monopoli dalam Black's Law Dictionary. “Monopoly is a previlege or peculiar advantage vested in one or more persons or companies, consisting in the exclusive right (or power) to carry on a particular business or trade, manufacture a particular article, or control the sale of the wholesupply of a particular commodity. ${ }^{2}$

Undang-Undang Anti Monopoli merupakan sebuah Undang-Undang yang secara khusus mengatur persaingan dan praktek monopoli, yang sudah sejak lama dipikirkan oleh para pakar, partai politik, lembaga swadaya masyarakat, serta instansi pemerintah. Sebagai contoh, misalnya Partai Demokrasi Indonesia pada tahun 1995

\footnotetext{
${ }^{1}$ Hikmahanto Juana, , Sekilas tentang Hukum Persaingan dan UU No. 5 Tahun 1999, Jurnal Magister Hukum I Tahun 1999, h. 32.

${ }^{2}$ Bryan A. Garner, Black’s Law Dictionary, Eight Edition, West A Thompson Business, 2004
} 
telah mengeluarkan gagasan tentang konsep Rancangan Undang-Undang tentang Anti Monopoli. Namun demikian, semua gagasan dan usulan tersebut tidak mendapat tanggapan yang positif, karena pada masa itu belum ada komitmen maupun political will dari elite politik yang berkuasa untuk mengatur masalah persaingan usaha.

Segala sesuatu tentang penulisan ulang mengenai ilmu ekonomi pastinya bersifat terbuka dan milik hak semua orang. Hanya bagaimana cara kita mengaplikasikannya secara baik dan benar. Kenyataanya di zaman sekarang ini masih banyak yang menyalah gunakan tentang prilaku monopoli, bahkan banyak dikalangan pengusaha yang melakukan hal-hal yang tidak seharusnya dalam melakukan monopoli.

Untuk itulah diperlukan pemerintah sebagai regulator hukum ekonomi. Diperlukan hukum anti monopoli yang kuat untuk mencegah terjadinya penguasaan ekonomi secara massive dan terus menerus oleh segelintir pihak. Dengan adanya hukum ekonomi dan penegakan hukumnya niscaya akan tercapai situasi pasar yang kondusif dan bergairah sehingga meningkatkan perekonomian nasional. Selain itu pemerintah juga dituntut untuk selalu memperbarui hukum ekonominya agar tidak tertinggal dengan laju perekonomian global yang selalu berkembang karena pengaruh derasnya perkembangan arus transportasi, teknologi dan informasi akibat globalisasi.

Pasar bebas secara etimologi adalah pasar ideal, di mana seluruh keputusan ekonomi dan aksi oleh individu yang berhubungan dengan uang, barang, dan jasa adalah sukarela. Pasar bebas diadvokasikan oleh pengusul ekonomi liberalisme. ${ }^{3}$ Sangat penting saat ini negara kita menata dan berbenah dalam pasar karena saat ini sudah tak terbendung lagi pemberlakuan pasar bebas di ASEAN (MEA).

Dalam tulisan ini akan dibahas mengenai pengertian Monopoli, ruang lingkup hukum anti Monopoli, dampak positif dan negatif perilaku Monopoli dan tantangan Undang-Undang Anti Monopoli dan Persaingan Usaha tidak Sehat dalam Pasar Bebas. Tujuan dari tulisan ini tidak lain untuk memperkaya nuansa ilmu hukum ekonomi dalam memahami perilaku monopoli dan dampaknya baik positif maupun negatif serta tantangan Undang-Undang Anti Monopoli dan Persaingan Usaha Tidak Sehat (UU No. 5 Tahun 1999) dalam pasar bebas yang berlaku saat ini.

\footnotetext{
${ }^{3}$ https://id.wikipedia.org/wiki/Pasar_bebas, diakses tanggal 12 April 2017 jam 21.44 wita
} 


\section{Pratjaja Winrekso}

\section{Pembahasan}

Undang-Undang Anti Monopoli merupakan sebuah Undang-Undang yang secara khusus mengatur persaingan dan praktek monopoli, yang sudah sejak lama dipikirkan oleh para pakar, partai politik, lembaga swadaya masyarakat, serta instansi pemerintah. Sebagai contoh, misalnya Partai Demokrasi Indonesia pada tahun 1995 telah mengeluarkan gagasan tentang konsep Rancangan Undang-Undang tentang Anti Monopoli. Namun demikian, semua gagasan dan usulan tersebut tidak mendapat tanggapan yang positif, karena pada masa itu belum ada komitmen maupun political willdari elite politik yang berkuasa untuk mengatur masalah persaingan usaha. ${ }^{4}$

\section{A. Pengertian Pasar Bebas}

Pasar bebas merupakan sebuah pasar dimana penjual dan pembeli memiliki kebebasan penuh dalam menetapkan masalah perdagangan dan juga bisnisnya. Bisa juga disebut dalam sistem ekonomi pasar bebas dimana baik penjual ataupun pembeli mempunyai kebebasan penuh dalam menyelenggarakan berbagai kegiatan perdagangan mereka. Akan tetapi meskipun namanya pasar bebas, pada dasarnya tidak benar-benar bebas, karena masih ada aturan-aturan tertentu yang harus dipatuhi oleh kedua pihak.

Definisi lainnya dari pasar pasar bebas ialah suatu proses kegiatan ekonomi yang dilaksanakan dengan tanpa adanya suatu aturan atau hambatan buatan yang diterapkan oleh pemerintah dalam perdagangan antar perorangan dan perusahaan yang berada dinegara lain. Tanpa adanya suatu halangan dari pemerintah untuk melakukan perdagangan, pastinya ada kebebasan aturan, cara, dan jenis barang yang dijual. Efeknya, akan memunculkan suatu persaingan usaha dagang yang super ketat baik itu antar perorangan maupun perusahaan yang ada di negara yang berbeda, atau yang biasa kita sebut dengan istilah ekspor - impor atau proses penjualan dan proses pembelian yang dilaksanakan antar negara berbeda.

\section{a. Pengertian Pasar Bebas Menurut Beberapa Ahli}

- Adam Smith: pasar bebas merupakan wadah untuk menampung sesuatu yang dihasilkan oleh setiap orang yang berasal dari paham kebebasan yang

\footnotetext{
${ }^{4}$ Rachmadi Usman, Hukum Persaingan Usaha di Indonesia (Jakarta: Gramedia Pustaka Utama, 2004), h. 2
} 
disediakan kepada para pelaku ekonomi untuk mengusahakan kegiatan ekonomi sesuai dengan keinginan mereka tanpa adanya campur tangan dari pemerintah.

- David Ricardo: perdagangan bebas adalah suatu sistem dagang luar negeri yang mana tiap-tiap negara melakukan usaha dagangnya tanpa ada halangan dari negara itu sendiri.

\section{b. Ciri-ciri Sistem Ekonomi Pasar Bebas}

- Sumber produksi dan alat bisa dimiliki serta ditata oleh seseorang, masyarakat, maupun perusahaan.

- Terdapat pembagian kelas dalam masyarakat, yaitu kelas pekerja dan kelas pemilik modal.

- Adanya persaingan antar pengusaha untuk memperoleh keuntungan yang optimal atau sebesa-besarnya (profit motive).

- Tidak adanya campur tangan dari pemerintah dalam pasar. Lalu campur tangan dari negara terbatas hanya pada berbagai hal yang tidak bisa diusahakan oleh swasta, tetapi menjadi syarat terselenggaranya pasar bebas, contohnya keamanan negara.

\section{c. Kelebihan Sistem Ekonomi Pasar Bebas}

1. Setiap orang bebas memiliki kekayaan serta sumber daya produksi.

2. Kreatifitas dan inisiatif dari masyarakat dapat dikembangkan.

3. Adanya suatu persaingan antar produsen yang berakibat terciptanya berbagai macam produk yang berkualitas.

4. Efesiensi dan efektifitas yang tinggi karena tindakannya selalu atas dasar prinsip ekonomi.

\section{d. Kekurangan Sistem Ekonomi Pasar Bebas}

1. Terjadinya eksploitasi kepada masyarakan yang ekonominya lemah oleh pihak yang ekonominya kuat.

2. Bisa menimbulkan terjadinya monopoli yang dapat merugikan masyarakat.

3. Munculnya kesenjangan ekonomi antara golongan ekonomi kuat dengan ekonomi lemah.

4. Bisa menimbulkan ketidak stabilan perekonomian. 
Dimulai pada 2015 kemarin, kesepakatan Masyakarat Ekonomi ASEAN (MEA) atau pasar bebas ASEAN mulai berlaku. Jika ingin tetap bisa bersaing, Indonesia harus berbenah. Sebab, daya saing beberapa sektor industri utama kita masih kalah dibandingkan negara-negara ASEAN lainnya. Perlunya penataan sistem hukum kita dengan adanya Undang-Undang Anti Monopoli dan Persaingan Usaha Tidak Sehat yang kuat sehingga kita dapat antisipasi terjadinya monopoli oleh pemain industri yang kuat dan perbuatan curang segelintir industri dengan persaingan Usaha Tidak Sehatnya.

\section{B. Pengertian Monopoli}

Kata " monopoli " berasal dari kata Yunani yang berarti " penjual tunggal ". Disamping itu istilah monopoli sering disebut juga "Antitrust" untuk pengertian yang sepandan dengan istilah " antimonopoli " atau istilah "dominasi” yang dipakai oleh masyarakat Eropa yang artinya sepadan dengan arti istilah " monopoli " dikekuatan pasar. Dalam praktek keempat istilah tersebut yaitu istilah monopoli, antitrust, kekuatan pasar dan istilah dominasi saling ditukarkan pemakaiannya.Keempat istilah tersebut dipergunakan untuk menunjukan suatu keadaan dimana seseorang menguasai pasar, dimana pasar tersebut tidak tersedia lagi produk subtitusi atau produk subtitusi yang potensial dan terdapatnya kemampuan pelaku pasar tersebut untuk menerapkan harga produk tersebut yang lebih tinggi, tanpa mengikuti hukum persaingan pasar atau hukum tentang permintaan pasar.

Pelaku usaha adalah setiap orang atau pun badan usaha, baik yang berbentuk badan hukum atau tidak, yang didirikan atau berkedudukan atau melakukan kegiatan dalam wilayah Republik Indonesia yang menyelenggarakan berbagai kegiatan dalam bidang ekonomi.

\section{Ruang Lingkup Hukum Anti Monopoli}

Tujuan Undang-Undang Anti Monopoli ini adalah untuk memangkas praktek monopoli dan persaingan usaha yang tidak sehat yang merajalela di Indonesia pada zaman pemerintah orde baru, dimana praktek monopoli dan persaingan usaha tidak sehat tersebut banyak terjadi kebijakan pemerintah yang kerap kali menguntungkan 
pelaku usaha tertentu saja. Undang-Undang Anti Monopoli telah melewati sepuluh tahun keberadaannya di Indonesia, namun banyak kontroversi yang muncul, salah satu penyebab kontroversi tersebut adalah Undang-Undang Anti Monopoli kurang rinci mengatur penyelesaian perkara-perkara persaingan usaha, dan terutama peran lembaga peradilan dalam menangani keberatan terhadap Keputusan Komisi Pengawas Persaingan Usaha (selanjutnya disebut "KPPU”).

Komisi Pengawas Persaingan Usaha (KPPU) dibentuk atas amanat UndangUndang No. 5 Tahun 1999 tentang Larangan Praktek Monopoli dan PersainganUsaha Tidak Sehat untuk mengawasi pelaksanaan Undang-Undang No. 5 Tahun 1999. Undang-Undang No. 5 Tahun 1999 memuat ketentuan yang melarang berbagai bentuk kegiatan usaha yang dapat mengakibatkan praktek monopoli dan persaingan usaha tidak sehat, yaitu perjanjian yang dilarang, kegiatan yang dilarang, dan penyalahgunaan posisi dominan. Di samping berbagai bentuk larangan tersebut, Undang-Undang No. 5 Tahun 1999 mengatur pula mengenai ketentuan pengecualian terhadap berlakunya Undang-Undang No. 5 Tahun 1999 sebagaimana diatur dalam Pasal 50 dan ketentuan Pasal 51 tentang Badan Usaha Milik Negara dan atau badan atau lembaga yangdiberi wewenang atau hak khusus dalam melakukan kegiatan usahanya

Berdasarkan Undang - Undang No 5 Tahun 1999, maka ruang lingkup antimonopoli tersebut adalah sebagai berikut :

1. Perjanjian yang dilarang. Perjanjian yang dilarang sebagaimana dimaksud dalam UU No 5 Tahun 1999 mencakup oligopoly, penetapan harga, pembagian wilayah, pemboikotan, kartel, trust, oligopsoni, integrasi vertikal, perjanjian tertutup, dan perjanjian dengan pihak luar negeri.

2. Kegiatan yang dilarang. Kegiatan yang dilarang sebagaimana dimaksud dalam UU No 5 Tahun 1999 mencakup monopoli, monopsoni, penguasaan pasar, dan persekongkolan.

3. Penyalahgunaan posisi dominan. Penyelahgunaan posisi dominan mencakup jabatan rangkap, kepemilikan saham dan merger, akuisisi, dan konsolidasi.

4. Komisi Pengawas Persaingan Usaha

5. Tata cara penanganan perkara 
6. Sanksi sanksi

7. Perkecualian perkecualian

Dari keseluruhan ruang lingkup yang ada pada Undang Undang No 5 Tahun 1999, penulis lebih menekankan pada kegiatan yang dilarang sebagaimana terdapat dalam pasal 22 tentang persekongkolan.

Persekongkolan menurut UU No 5 Tahun 1999 Tentang Larangan Praktek Monopoli dan Persaingan Usaha Tidak Sehat memiliki 3 pengertian, yaitu :

1. Persekongkolan untuk mengatur pemenang tender

Undang-undang Anti Monopoli melarang setiap persekongkolan oleh pelaku usaha dengan pihak lain dengan tujuan untuk mengatur dan atau menentukan pemenang suatu tender. Hal tersebut jelas merupakan perbuatan curang dan tidak fair terutama bagi peserta tender lainnya.Sebab, sudah lazim dalam istilah "tender" bahwa pemenangnya tidak dapat diatur-atur, melainkan siapa yang melakukan penawaran yang terbaik dialah yang menang.Karena itu, perbuatan persekongkolan untuk mengatur atau menentukan pemenang tender dapat mengakibatkan terjadinya suatu persaingan usaha yang tidak sehat.

Menurut Penjelasan Pasal 22 dari Undang-undang Anti Monopoli, yang dimaksudkan dengan tender dalam hal ini adalah tawaran untuk mengajukan harga untuk memborong suatu pekerjaan, untuk mengadakan barang-barang, atau untuk menyediakan suatu jasa.

2. Persekongkolan untuk memperoleh rahasia perusahaan

Sebagaimana diketahui bahwa yang namanya "rahasia perusahaan" adalah property dari perusahaan yang bersangkutan. Karenanya tidak boleh dicuri, dibuka atau dipergunakan oleh orang lain tanpa seijin pihak perusahaan yang bersangkutan. Ini adalah prinsip hukum bisnis yang sudah berlaku secara universal.

Karena itu pula, Undang-undang Anti Monopoli dilarang terhadap tindakan persekongkolan antara seorang pelaku usaha dengan pihak lain untuk mendapatkan informasi tentang kegiatan usaha pesaingnya yang diklasifikasikan sebagai rahasia perusahaan. Karena hal tersebut dianggap dapat mengakibatkan terjadinya suatu pesaingan usaha tidak sehat. 
Larangan bersekongkol mendapatkan rahasia perusahaan dalam Pasal 23 tersebut menekankan kepada rahasia perusahaan tersebut. Artinya apabila dapat dibuktikan ada rahasia perusahaan yang didapati secara bersekongkol, maka larangan oleh pasal pasal tersebut sudah dapat diterapkan, karena "demi hukum" telah dianggap adnya suatu persaingan usaha tidak sehat, tanpa perlu harus dibuktitikan lagi persaingan usasha tidak sehat tersebut.

3. Persekongkolan untuk menghambat pasokan produk.

Salah satu strategi tidak sehat dalam berbisnis adalah dengan berupaya agar produk-produk dari si pesaing menjadi tidak baik dari segi mutu, jumlah atau ketetapan waktu ketersedianya atau waktu yang telah dipersyratkan.

Karena itu, Undang-undang Anti Monopoli dengan tegas melarang terhadap setiap persekongkolan oleh pelaku usaha dengan pihak lain yang dibuat dengan tujuan untuk menghambat produksi dan atau pemasaran suatu produk dari pelaku usaha pesaingnya dengan harapan agar produk yang dipasok atau ditawarkan tersebut menjadi kurang baik dari segi kualitasnya, dari segi jumlahnya, maupun dari segi ketetapan waktu yang dipersyaratkan.

\section{Dampak Hukum Bagi Pelaku Usaha}

Persaingan usaha yang sehat akan berakibat positif bagi para pengusaha yang saling bersaing atau berkompetisi karena dapat menimbulkan upaya-upaya peningkatan efisiensi, produktivitas, dan kualitas produk yang dihasilkan ${ }^{5}$.

Dampak hukum yang dapat dikenakan kepada pelaku usaha yang telah melakukan pelanggaran terhadap praktek monopoli dan persaingan usaha tidak sehat adalah berupa sanksi. Dimana sanksi tersebut dapat berupa :

1. Sanksi Administratif

Berdasarkan pasal 47 UU No 5 Tahun 1999, maka KPPU berhak untuk menjatuhkan sanksi administratif bagi pelaku usaha yang telah terbukti melakukan pelanggaran. Sanksi tersebut dapat berupa :

${ }^{5}$ Abdul R. Saliman dan kawan-kawan, Esensi Hukum Bisnis Indonesia Teori dan Contoh Kasus, (Jakarta : Kencana, 2004), h. 170. 


\section{Pratjaja Winrekso}

a. Penetapan pembatalan perjanjian yang telah dibuat oleh para pelaku usaha sebagaimana dimaksud dalam pasal 4 sampai apsal 13, pasal 15 dan pasal 16 Perintah kepada usaha untuk menghentikan integrasi vertikal sebagaimana dimaksud dalam pasal 14; dan atau Perintah kepada pelaku usaha untuk menghentikan kegiatan yang terbukti menimbulkan praktek monopoli dan atau menyebabkan persaingan usaha tidak sehat dan atau merugikan masyarakat; dan atau Perintah kepada pelaku usaha untuk menghentikan penyalahgunaan posisi dominan; dan atau

b. Penetapan pembatalan atas penggabungan atau peleburan badan usaha dan pengambilalihan saham sebagaimana dimaksud dalam pasal 28; dan atau Penetapan pembayaran ganti rugi; dan atau Pengenaan denda serendahrendahnya $\mathrm{Rp}$ 1.000.000,00 (satu miliar rupiah) dan setinggi-tingginya $\mathrm{Rp}$ 25.000.000.000,00 (dua puluh miliar rupiah)

\section{Sanksi Pidana}

Selain sanksi administratif, Hukum antimonopoli juga menyediakan sanksi pidana. Dimana saknsi pidana tersebut dibagi menjadi dua kategori, yaitu :

1. Sanksi Pidana Dalam UU No 5 Tahun 1999 yang terbagi menjadi 2 kategori sanksi lagi, yaitu:

Sanksi pidana pokok yang terdapat dalam pasal 48 UU No 5 Tahun 1999, yang berbunyi :

i. Pelanggaran terhadap ketentuan pasal 14, pasal 16 sampai dengan pasal 19 , pasal 25, pasal 27, dan pasal 28 diancam pidana serendah-rendahnya $\mathrm{Rp}$ 25.000.000.000,00 (dua puluh lima miliar rupiah) dan setinggitingginya $\mathrm{Rp}$ 100.000.000,00 (seratus miliar rupiah ), atau pidana kurungan pengganti denda selama-lamanya 6 (enam) bulan.

ii. Pelanggaran terhadap ketentuan pasal 5 sampai dengan pasal 8, pasal 15, pasal 20 sampai dengan pasal 24,dan pasal 26 Undang-undang ini diancam pidana denda serendah-rendahnya Rp 5.000.000.000,00 (lima miliar rupiah) dan setinggi-tingginya Rp 25.000.000.000,00 ( dua puluh lima miliar rupiah), atau pidana kurungan pengganti denda selamalamanya 5 (limi) bulan. 
iii. Pelanggaran terhadap ketentuan pasal 41 Undang-undang ini diancam pidana denda serendah-rendahnya $\mathrm{Rp}$ 1.000.000.000,00 (satu miliar rupiah) dan setinggi-tingginya $\mathrm{Rp}$ 5.000.000.000,00 (lima miliar rupiah), atau pidana kurungan pengganti denda selama-lamanya 3 (tiga) bulan Indonesia, UU No 5 Tahun 1999 Tentang Larangan Praktek Monopoli dan Persaingan Usaha Tidak Sehat, pasal 48.

2. Sanksi Pidana Tambahan yang terdapat dalam pasal 49 UU No 5 tahun 1999 yang berbunyi :

i. $\quad$ Pencabulan ijin usaha; atau

ii. Larangan kepada pelaku usaha yang telah terbukti melakukan pelanggaran terhadap Undang undang ini untuk menduduki jabatan direksi atau komisaris sekurang kurangnya dua tahun dan selama lamanya lima tahun

iii. Penghentian kegiatan atau tindakan tertentu yang menyebabkan timbulnya kerugian pada pihak lain.

3. Sanksi pidana dalam KUH Pidana.

Selain sanksi pidana yang terdapat didalam UU No 5 tahun 1999, maka ada pula sanksi pidana yang diatur dalam KUHP, yang terdapat dalam pasal 382 yang berbunyi : “ barang siapa untuk mendapatkan, melangsungkan atau memperluas hasil perdagangan atau perdagangan atau perusahaan milik sendiri atau orang lain, melakukan perbuatan curang untuk menyesatkan khalayak umum atau seorang tertentu, diancam karena persaingan curang, dengan pidana penjara paling lama satu tahun empat bulan denda paling banyak tiga belas ribu lima ratus rupiah, bila perbuatan itu dapat menimbulkan kerugian bagi konkuren-konkurennya atau konkuren-konkuren orang lain itu”. Indonesia, KUHP, Pasal 282.

Secara umum, semua orang adalah sama kedudukannya dalam hukum, berhak atas pekerjaan dan penghidupan yang layak bagi kemanusiaan. Hak perseorangan dilindungi oleh hukum. Hak perseorangan adalah relatif, sifat perseorangan dalam hukum perjanjian menimbulkan gejala-gejala hukum sebagai akibat hubungan hukum antara persoondengan persoonlainnya. Konsep hukum dan teori hukum dalam sistem mendekatkan hukum pada permasalahan peran sekaligus 
fungsi hukum. Orang (termasuk dalam pengertian kelembagaan) dapat melakukan sesuatu kehendak melalui pemanfaatan hukum ${ }^{6}$.

Dilihat dari segi judul dan permasalahan diatas, maka perlu dijelaskan terlebih dahulu mengenai hal tertentu sebagai berikut :

Berdasarkan UU No 5 tahun 1999 Tentang Larangan Praktek Monopoli dan Persaingan Usaha Tidak Sehat yang dimaskud dengan pergertian :

1. Monopoli adalah penguasaan barang atau produksi dan atau pemasaran barang dan atau pengunaan jasa tertentu oleh satu pelaku usaha atau satu kelompok pelaku usaha.

2. Praktek monopoli adalah Pemusatan kekuatan ekonomi oleh satu atau lebih pelaku usaha yang mengakibatkan dikuasainya produksi dan atau pemasaran barang dan atau jasa tertentu sehingga menimbulkan persaingan usaha tidak sehat dan dapat merugikan kepentingan umum.

3. Pelaku usaha adalah setiap orang perorangan atau badan usaha, baik yang berbentuk bedan hukum atau bukan badan hukum yang didirikan dan berkedudukan atau melakukan kegiatan dalam wilayah hukum negara Republik Indonesia, baik sendiri maupun bersama sama melalui perjanjian, menyelenggarakan berbagai kegiatan usaha dalam bidang ekonomi.

4. Persaingan usaha tidak sehat adalah persaingan antar pelaku usaha dalam menjalankan kegiatan produksi dan atau pemasaran barang dan atau jasa yang dilakukan dengan cara tidak jujur atau melawan hukum atau menghambat persaingan usaha.

5. Persekongkolan atau konspirasi usaha adalah bentuk kerjasama yang dilakukan oleh pelaku usaha dengan pelaku usaha lain dengan maksud untuk menguasai pasar bersangkutan bagi kepentingan pelaku usaha yang bersekongkol.

6. Barang adalah setiap benda, baik yang berwujud at au tidak berwujud, baik bergerak maupun tidak bergerak, yang dapat diperdagangkan, dipakai, dipergunakan atau dimanfaatkan oleh konsumen atau pelaku usaha.

${ }^{6}$ Mahfud M.D., Pergulatan Politik dan Hukum di Indonesia, (Jakarta : Gramedia, 1999), hal 69 
7. Jasa adalah setiap layanan yang berbentuk pekerjaan atau prestasi yang diperdagangkan dalam masyarakat untuk dimanfaatkan konsumen atau pelaku usaha.

Komisi Pengawas Persaingan Usaha adalah komisi yang dibentuk untuk mengawasi pelaku usaha dalam menjalankan kegiatan usahanya agar tidak melakukan praktek monopoli dan persaingan usaha tidak sehat.

\section{E. Dampak Positif dan Negatif Perilaku Monopoli}

Dampak positif globalisasi Monopoli dilihat dari aspek kreatifitas dan daya saing dengan semakin terbukanya pasar untuk produk-produk ekspor maka diharapkan tumbuhnya kreatifitas dan peningkatan kualitas produksi yang disebabkan dorongan untuk tetap eksis ditengah persaingan global, secara natural ini akan terjadi manakala kesadaran akan keharusan berinovasi muncul dan pada giliranya akan menghasilkan produk2 dalam negeri yang handal dan berkualitas.

Disisi lain kondisi dimana kapababilitas daya saing yang rendah dan ketidakmampuan Indonesia mengelola persaingan akan menimbulkan mimpi buruk begi perekonomian negeri ini, hal ini akan mendatangkan berbaga dampak negatif globalisasi ekonomi seperti membajirnya produk2 negeri asing seperti produk cina yang akhirnya mamatikan produksi dalam negeri, warga negara Indonesia hanya akan menjadi tenaga kasar bergaji murah sedangkan pekerjaan pekerjaan yang membutuhkan skill akan dikuasai ekspatriat asing, dan sudah barang tentu lowongan pekerjaan yang saat ini sudah sangat sempit akan semakin habis karena gelombang pekerja asing.

Dampak positif globalisasi ekonomi dari aspek permodalan, dari sisi ketersediaan akses dana akan semaikin mudah memperoleh investasi dari luar negeri. Investasi secara langsung seperti pembangunan pabrik akan turut membuka lowongan kerja. hanya saja dampak positif ini akan berbalik 180 derajat ketika pemerintah tidak mampu mengelola aliran dana asing, akan terjadi justru penumpukan dana asing yang lebih menguntungkan pemilik modal dan rawan menimbulkan krisis ekonomi karena runtuhnya nilai mata uang Rupiah. Belum lagi ancaman dari semakin bebas dan mudahnya mata uang menjadi ajang spekulasi.Bayangkan saja jika sebuah investasi besar dengan meilbatkan tenaga kerja lokal yang besar tiba-tiba ditarik karena 
dianggap kurang prospek sudah barang tentu hal ini bisa memengaruhi kestabilan ekonomi.

Dampak positif globalisasi ekonomi dari sisi semakin mudahnya diperoleh barang impor yang dibutuhkan masyarakat dan belum bisa diproduksi di Indonesia, alih tehnologi juga bisa terbuka sangat lebar, namun kondisi ini juga bisa berdampak buruk bagi masyarakat karena kita cenderung hanya dijadikan objek pasar, studi kasus seperti produksi motor yang di kuasai Jepang, Indonesia hanya pasar dan keuntungan penjualan dari negeri kita akan dibawa ke Jepang memperkaya bangsa Jepang. Dampak positif globalisasi ekonomi dari aspek meningkatnya kegiatan pariwisata, sehingga membuka lapangan kerja di bidang pariwisata sekaligus menjadi ajang promosi produk Indonesia.

Dampak negatif dari perilaku monopoli Globalisasi dan liberalisme pasar dikampayekan oleh para pengusungnya sebagai cara untuk mencapai standar hidup yang lebih tinggi, namun bagi para penentangnya globalisasi hanya kedok para kapitalis yang akan semakin melebarnya ketimpangan distribusi pendapatan antar negara kaya dengannegara berkembang dan miskin. Penguasaan kapital yang lebih besar dengan menciptakan pasar global.

Sebuah atau beberapa perusahaan yang memonopoli produk tertentu dapat menentukan harga suatu produk sesuka hatinya, karena mekanisme pasar tidak berjalan lagi. Apalagi produk yang dimonopoli kebutuhan primer. Dapat dipastikan mereka akan mengeruk keuntungan yang sebesar-besarnya. Masyarakat tidak ada pilihan lain kecuali membeli produk monopoli itu ${ }^{7}$.

Monopoli dapat terjadi dalam setiap sistem ekonomi. Dalam sistem ekonomi kapitalisme dan liberalisme, dengan instrumen adanya kebebasan pasar, kebebasan keluar masuk tanpa restriksi, serta informasi dan bentuk pasarnya yang atomistik monopolistik telah melahirkan monopoli sebagai anak kandungnya. Adanya persaingan tersebut mengakibatkan lahirnya perusahaan-perusahaan yang secara naluriah ingin mengalahkan pesaing-pesaingnya agar menjadi yang paling besar, paling hebat, dan paling kaya.

\footnotetext{
${ }^{7}$ Susanti Adi Nugroho, Hukum Persaingan Usaha di Indonesia, Dalam Teori dan Praktik serta Penerapan Hukumnya, (Jakarta: Kencana Prenada Media Group, 2012)
} 
Dalam sistem ekonomi sosialisme dan komunisme, monopoli juga terjadi dengan bentuk yang khas. Dengan nilai instrumental perencanaan ekonomi yang sentralistik mekanistik dan pemilikan faktor produksi secara kolektif, segalanya dimonopoli negara dan diatur dari pusat ${ }^{8}$

Sedangkan di Indonesia dengan sistem ekonomi pancasila, kita mencoba menghilangkan ciri-ciri negatif yang terkandung dalam sistem liberalisme dan sosialisme. Ciri-ciri negatif seperti free figh liberalism, yang membenarkan eksploitasi terhadap manusia, etatisme di mana negara beserta aparatur ekonomi negara bersifat dominan serta mendesak dan meminimumkan potensi dan daya kreasi unit ekonomi di luar sektor negara, dan pemusatan ekonomi pada salah satu kelompok dalam bentuk monopoli yang merugikan masyarakat.

\section{Landasan Yuridis Philosofis}

Dalam UU No 5 Tahun 1999 disebutkan pula tentang landasan Yuridis Philosofis dalam bidang perekonomian Indonesia yaitu ketentuan Pasal 33 ayat (1) UUD 1945, sebagai landasan pokok yang kuat bagi perekonomian Indonesia. Landasan Yuridis philosofis ini sebelumnya telah dicanangkan dalam landasan kebijakan ekonomi Indonesia dalam era pemerintahan Orde Baru. Kebijakan tersebut telah digariskan dalam Tap MPRS RI No. XXII/MPRS/1966 yang mengatur tentang Pembaharuan Kebijaksanaan Ekonomi, Keuangan dan Pembangunan. Dalam Pasal 7 (c) Tap MPRS RI No. XXII/MPRS/1966 lebih lanjut disebutkan, bahwa “ dalam demokrasi ekonomi di Indonesia, sudah tidak ada tempat bagi monopoli yang merugikan masyarakat." Namun sayang Tap MPRS tersebut dilanggar sendiri oleh rezim Orde Baru dengan praktek Korupsi, Kolusi dan Nepotisme-nya.

Dalam pasal 33 Undang-undang dasar 1945 dapat kita lihat ciri-ciri positif yang hendak kita capai dan mempertahankan dalam sistem perekonomian kita. Perekonomian disusun sebagai usaha bersama atas asas kekeluargaan, Cabang produksi yang penting bagi negara dan mengenai hajat hidup orang banyak dikuasai oleh negara serta bumi dan air beserta kekayaan alam yang terkandung didalamnya digunakan sebesar-besarnya untuk kemakmuran rakyat. Jadi secara implisit, UUD 1945 juga

\footnotetext{
${ }^{8}$ Susanti Adi Nugroho, Hukum Persaingan Usaha di Indonesia, Dalam Teori dan Praktik serta Penerapan Hukumnya, h. 88
} 


\section{Pratjaja Winrekso}

mengakui adanya monopoli berupa penguasaan sektor-sektor yang menguasai hajat hidup orang banyak. Ini terealisasi dari penguasaan yang dilakukan oleh badan usaha milik negara atas bidang tertentu. Misalnya PLN menguasai listrik, Pertamina memonopoli minyak dan gas bumi, PT Kereta Api Indonesia menguasai perkeretaapian.

Akibat dari adanya globalisasi, secara tidak langsung budaya pasar bebas (free trade market) yang dibawa kaum liberalis akan berpengaruh pula pada pasar di Indonesia. Terbentuknya Masyarakat Ekonomi ASEAN salah satu contohnya. Oleh karenanya diperlukan Hukum Ekonomi yang kuat agar Monopoli pasar tidak terjadi dan Persaingan usaha tidak sehat dapat dihilangkan. Tantangan global Undang-Undang No. 5 Tahun 1999 tentang Anti Monopoli dan Persaingan Usaha Tidak Sehat dalam pasar bebas lebih utama adalah pada perlindungan hukum terhadap produk-produk dan industri dalam negeri dan lebih utama adalah kepastian hukum bagi produk-produk yang berasal dari luar negeri. Produk dan industri dalam negeri juga memperoleh kepastian hukum baik dalam hal permasalahan persaingan usaha tidak sehat maupun antisipasi terjadinya monopoli.

\section{Penutup}

Berdasarkan Undang - Undang No 5 Tahun 1999 , maka ruang lingkup antimonopoli tersebut adalah sebagai berikut :

1. Perjanjian yang dilarang. Perjanjian yang dilarang sebagaimana dimaksud dalam UU No 5 Tahun 1999 mencakup oligopoly, penetapan harga, pembagian wilayah, pemboikotan, kartel, trust, oligopsoni, integrasi vertikal, perjanjian tertutup, dan perjanjian dengan pihak luar negeri.

2. Kegiatan yang dilarang. Kegiatan yang dilarang sebagaimana dimaksud dalam UU No 5 Tahun 1999 mencakup monopoli, monopsoni, penguasaan pasar, dan persekongkolan.

3. Penyalahgunaan posisi dominan. Penyelahgunaan posisi dominan mencakup jabatan rangkap, kepemilikan saham dan merger, akuisisi, dan konsolidasi.

Dampak positif globalisasi Monopoli dilihat dari aspek kreatifitas dan daya saing dengan semakin terbukanya pasar untuk produk-produk ekspor maka diharapkan 
tumbuhnya kreatifitas dan peningkatan kualitas produksi yang disebabkan dorongan untuk tetap eksis ditengah persaingan global, secara natural ini akan terjadi manakala kesadaran akan keharusan berinivasi muncul dan pada giliranya akan menghasilkan produk2 dalam negeri yang handal dan berkualitas.

Tantangan global Undang-Undang No. 5 Tahun 1999 tentang Anti Monopoli dan Persaingan Usaha Tidak Sehat dalam pasar bebas lebih utama adalah pada perlindungan hukum terhadap produk-produk dan industri dalam negeri dan lebih utama adalah kepastian hukum bagi produk-produk yang berasal dari luar negeri. Produk dan industri dalam negeri juga memperoleh kepastian hukum baik dalam hal permasalahan persaingan usaha tidak sehat maupun antisipasi terjadinya monopoli. 


\section{DAFTAR PUSTAKA}

Abdul R. Saliman dan kawan-kawan, Esensi Hukum Bisnis Indonesia Teori dan Contoh Kasus, Jakarta : Kencana, 2004

Arthur Lewis, Introduction to Business Law, Tudor Business Publishing Ltd, New York USA, 1998

Adikusuma, Hilman, Jual Beli, Bandung:Citra Aditya Bakti, 1993.

Darajat, Zakiah, Prof, Dr, Perbandingan Pasar monopoli dan non monopoli, Jakarta:Bulan Bintang, 1993.

Hikmahanto Juana, Sekilas tentang Hukum Persaingan dan UU No. 5 Tahun 1999, Jurnal Magister Hukum I Tahun 1999, 1999.

Mahfud M.D., Pergulatan Politik dan Hukum di Indonesia, Jakarta : Gramedia, 1999

Susanti Adi Nugroho, Hukum Persaingan Usaha di Indonesia, Dalam Teori dan Praktik serta Penerapan Hukumnya, Kencana Prenada Media Group, Jakarta, 2012. 